Provided for non-commercial research and education use. Not for reproduction, distribution or commercial use.

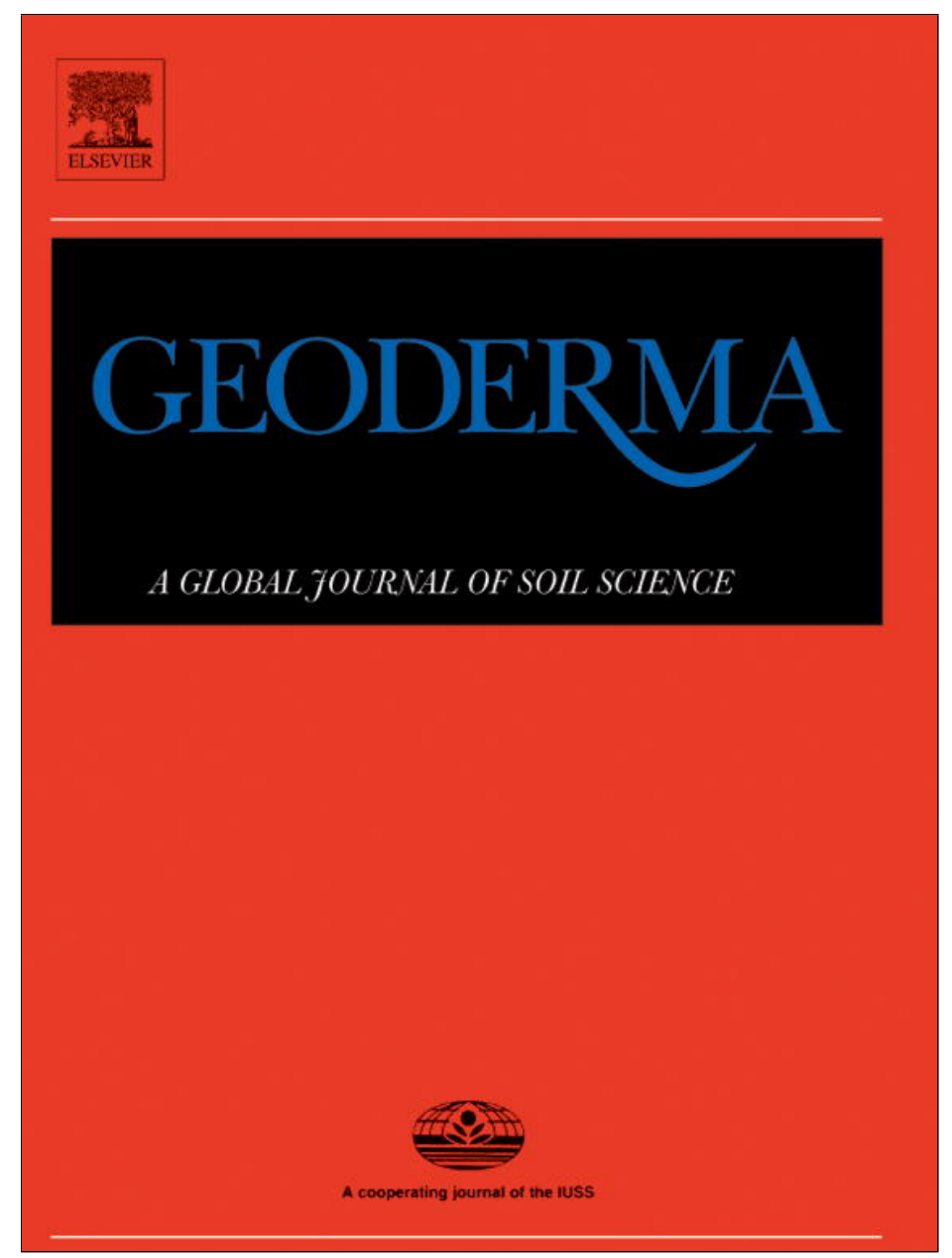

This article appeared in a journal published by Elsevier. The attached copy is furnished to the author for internal non-commercial research and education use, including for instruction at the authors institution and sharing with colleagues.

Other uses, including reproduction and distribution, or selling or licensing copies, or posting to personal, institutional or third party websites are prohibited.

In most cases authors are permitted to post their version of the article (e.g. in Word or Tex form) to their personal website or institutional repository. Authors requiring further information regarding Elsevier's archiving and manuscript policies are encouraged to visit:

http://www.elsevier.com/authorsrights 


\title{
Soil water repellency in riparian systems invaded by Eucalyptus camaldulensis: A restoration perspective from the Western Cape Province, South Africa
}

\author{
Sheunesu Ruwanza ${ }^{\text {a,* }}$, Mirijam Gaertner ${ }^{\text {a }}$, David M. Richardson ${ }^{\text {a }}$, Karen J. Esler ${ }^{\text {b }}$ \\ a Centre for Invasion Biology, Department of Botany and Zoology, Private Bag X1, 7602 Matieland, Stellenbosch University, South Africa \\ ${ }^{\mathrm{b}}$ Centre for Invasion Biology, Department of Conservation Ecology and Entomology, Private Bag X1, 7602 Matieland, Stellenbosch University, South Africa
}

\section{A R T I C L E I N F O}

\section{Article history:}

Received 30 November 2011

Received in revised form 22 January 2013

Accepted 25 January 2013

Available online $\mathrm{xxxx}$

\section{Keywords:}

Biological invasions

Critical surface tension (CST)

Infiltration

Rehabilitation

Soil hydrophobicity

Water drop penetration time (WDPT)

\begin{abstract}
A B S T R A C T
South African riparian systems are threatened by major alien plant invasions through the widespread replacement of native plant species by fast-growing alien species, including several Eucalyptus species. Since Eucalyptus species are known to cause soil water repellency, this study examined the occurrence of soil water repellency coupled with soil moisture and infiltration under laboratory conditions from soils collected along the Berg River which is heavily invaded by alien tree species, especially E. camaldulensis. The connection between alien clearing for restoration purposes and soil water repellency is important as it has the potential to affect the success of native vegetation recovery. The topsoil was sampled at 12 sites, under different restoration treatments, namely invaded by Eucalyptus, completely cleared, thinned and native (control) sites. The water drop penetration time (WDPT) and the critical surface tension (CST) methods were performed. Soil moisture was found to be higher in invaded and natural sites compared to completely cleared and thinned sites. Soil water repellency, measured with the WDPT test on dried samples taken at 5-10 cm depth, differed with invasion status and/or restoration condition. In invaded sites water repellency varied from wettable to severely water repellent: in thinned sites from non-repellent to strongly water repellent; in natural sites from wettable to slightly water repellent; all samples from completely cleared sites were wettable. Soil water repellency had no impact on soil infiltration rates. We conclude that the removal of invasive Eucalyptus species has the potential to restore soils to a non-repellent state, thus improving soil related ecosystem functions, which will facilitate the restoration of indigenous species, vegetation composition and structure.
\end{abstract}

(c) 2013 Elsevier B.V. All rights reserved.

\section{Introduction}

Water repellency, the inability of water to wet or infiltrate soils (Dekker et al., 2005), is a widespread phenomenon in soils under a range of land use types and climates (Rodriguez-Alleres and Benito, 2011). Its severity depends on a number of factors including the amount of soil organic matter and micro-organisms present (Dekker and Ritsema, 1994), soil moisture and texture (Doerr and Thomas, 2000), wetting and drying history as well as temperature (Dekker et al., 2005), relative humidity (Coelho et al., 2005) and fire (Dekker and Ritsema, 1994; Doerr and Thomas, 2003). Many of these factors are associated with vegetation type (Scott, 2000) and studies have also shown that certain plant species e.g. citrus, pines and eucalypts (Crockford et al., 1991) play a role in the development of soil water repellency.

The occurrence of repellency is generally thought to follow a seasonal distribution, becoming most extreme during dry periods and declining or disappearing after long wet periods (Crockford et al., 1991). Although several approaches have been used to quantify soil water repellency, the

\footnotetext{
* Corresponding author. Tel.: +27 21808 2339; fax: +27 218082995.

E-mail addresses: sheunesu@sun.ac.za, ruwanza@yahoo.com (S. Ruwanza).
}

water drop penetration time (WDPT) and the Critical Surface Tension (CST) methods are most widely used because of their convenience and accuracy (Scott, 1993). Consequences of soil water repellency include reduced infiltration capacity, an unstable wetting front (boundary between the wet and drier soil) (Coelho et al., 2005), preferential flow (the process whereby water and its constituents flows unevenly through preferred soil pathways), faster transport of solutes, variations in soil water content (Dekker and Ritsema, 1994) and enhanced overland flow and soil erosion (Scott, 1993; Shakesby et al., 1993). The modified soils arising from water repellency can induce poor plant growth (Doerr and Thomas, 2000) thereby posing negative effects on agricultural productivity and environmental sustainability (DeBano, 1991).

Many riparian systems in South Africa are invaded by alien trees (Galatowitsch and Richardson, 2005). These alien tree invasions have major impacts; they outcompete indigenous vegetation for water (Dye and Poulter, 1995), soil nutrients (Yelenik et al., 2004) and organic matter (Galatowitsch and Richardson, 2005), thereby altering species composition and structure and ecosystem function (Richardson et al., 2007). The invasion of riparian habitats by woody plants also increases water loss through the high evapotranspiration rates of alien trees compared with that of native flora (Le Maitre et al., 2000). These conditions have detrimental effects on agriculture, forestry and human health 
(Holmes et al., 2008; Richardson et al., 2000). Such negative effects of alien trees on riparian ecosystems and watersheds lead to the initiation of one of the world's largest programmes aimed at clearing invasive alien plants: the Working for Water (WfW) programme (Van Wilgen et al., 1998). The programme started in 1995 and operates under the assumption that target ecosystems, including riparian ecosystems, would "self-repair" once the main stressor (dense stands of invasive alien trees) had been removed. This approach often fails for various reasons, including the 'legacy effects' - long-lasting changes in ecosystem structure - that persist following the removal of invasive species (D'Antonio and Meyerson, 2002; Holmes et al., 2008). The result is that many control efforts are unsuccessful or even have unexpected, detrimental outcomes (e.g. Le Maitre et al., 2011). Prominent and thoroughly investigated legacy effects are for example changes in soil nutrient properties (Ehrenfeld, 2003; Le Maitre et al., 2011). In our study we investigate changes in soil water repellency as a potential legacy effect after alien species removal. To our knowledge no study has so far investigated soil legacy effects of water repellency on native species recovery.

The Berg River in the Western Cape Province has been invaded by the Australian red river gum Eucalyptus camaldulensis (hereafter "Eucalyptus") for more than 50 years. Apart from Australian acacias and pines, eucalypts are one of the major groups of alien tree invaders in South Africa (Forsyth et al., 2004). Due to Eucalyptus invasion, the condition of riparian vegetation along the Berg River has been described as poor (Foord et al., 2008). Also, large stands of Eucalyptus along the river have led to shading of the river channel, altered habitat type, and altered channel flow caused by fallen trees that create nick-points along the channel (Foord et al., 2008). Eucalyptus species are known to produce phenolic acids and volatile oils (Coelho et al. 2005) which are released into the soil during the decomposition of organic matter (Sasikumar et al., 2002). When soil particles are coated sufficiently by these acids and oils, drying can result in soils being repellent. This, though not tested, could affect the germination, growth and survival of native species thus hindering restoration along the Berg River. We therefore hypothesize that, if soil water repellency is enhanced by coating of soil particles by hydrophobic substances released by E. camaldulensis; the removal of this species should lower soil repellency. From a soil and restoration perspective, the removal of Eucalyptus has the potential to enhance soils by providing the necessary biophysical (organic material and microorganisms) and physical stimuli to enhance soil aggregation and stability, this can result in facilitating native species restoration (Peng et al., 2003).

Several studies have explained soil water repellency through conceptual models. Doerr and Thomas (2003) used soil moisture to explain soil water repellency. They suggested that when soil moisture rises above the critical soil moisture content, soils become wettable and when moisture is below the critical level soils become water repellent. We used our results to conceptualize changes in soil repellency in relation to restoration of the Berg River.

Current restoration initiatives do not consider the link between vegetation recovery and soil water repellency as an important connection that may affect the success of native vegetation recovery. However, soil water repellency can result in a persistent soil legacy effect that can negatively affect native species recovery. This study is the first to focus on soil water repellency as a "legacy effect" in relation to vegetation recovery after the clearing of invasive Eucalyptus trees in a riparian ecosystem. Our study objectives are (1) to investigate soil moisture differences in relation to restoration options conducted along the Berg River; (2) to examine the occurrence of soil water repellency in relation to restoration options conducted along the Berg River; and (3) to explore the effects of soil water repellency on infiltration. We also discuss the implications of the results for restoration of these habitats.

\section{Methods and materials}

\subsection{Study area and sites}

Soils were collected at different sites along the upper catchment of the Berg River which is located north of Cape Town in the Western Cape Province of South Africa (Fig. 1). The river is approximately

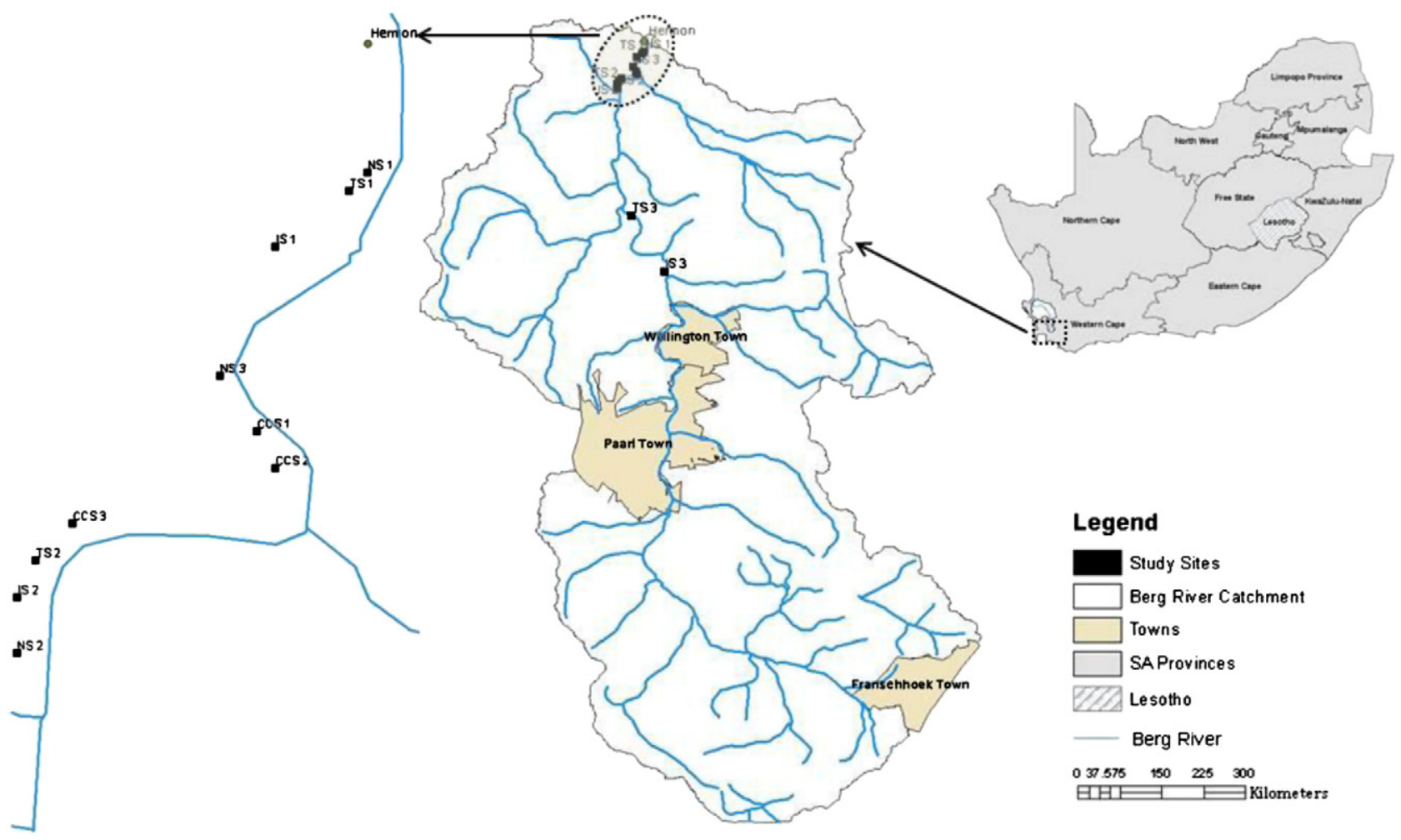

Fig. 1. Location of the study area and study sites in the Western Cape, South Africa. 
$294 \mathrm{~km}$ long with a catchment area of $7715 \mathrm{~km}^{2}$ (de Villiers, 2007). The geology of the catchment area is dominated by sandstone and quartzites of the Cape supergroup in the upper reaches, Cape granites in the middle reaches and recent sediments near the coast. The catchment is therefore characterised by nutrient-poor lithologies, however some areas consist of deep alluvial 'flood plain' with fertile sediments (de Villiers, 2007). Almost $50 \%$ of the catchment area is cultivated agricultural land, mainly vineyards, fruit trees and wheat fields. River flow peaks during the winter rainy season, from June to August, with rainfall averaging between 300 and $600 \mathrm{~mm}$ per annum (Mucina and Rutherford, 2006). The whole river stretch is heavily invaded by woody invasive alien plants mainly Eucalyptus (mostly E. camaldulensis) and Acacia species (mostly A. mearnsii).

Study sites were selected based on restoration initiatives (i.e. clearing type) that took place along the river. However, an attempt was made to control for slope, soil type and zonation. The four restoration treatments were (a) invaded sites (IS) - areas predominantly invaded by Eucalyptus stands (>65\% canopy cover), (2) thinned sites (TS) areas where Eucalyptus and acacia stands were selectively (partially) harvested by private companies between late 2005 and early 2006 (40-50\% alien cover removal), (3) completely cleared sites (CCS) areas where Eucalyptus and Acacia stands were completely harvested between late 2005 and early 2006 by Working for Water, and (4) natural sites (NS) - areas where stands of native species still exist (Table 1). Eucalyptus camaldulensis invasion in IS and TS appears to have started about 50 years ago (satellite image observations, see Tererai, 2012); however, the knowledge of how they were introduced is scarce (Geldenhuys, 2008). In TS mature E. camaldulensis trees (approximately $30 \mathrm{~m}$ high and $40 \mathrm{~cm}$ diameter at breast height) were harvested for commercial purposes with minimum soil disturbances. Ruwanza et al. (in press) estimated the thinning percentage by counting the tree stumps in 2010 and estimated E. camaldulensis thinning removal of between 40 and $50 \%$ which concurred with information from the WfW managers who administered thinning. The complete clearing operations in CCS involved the felling of alien trees (both Eucalyptus and any other existing aliens) with minimum soil damage and herbicide application to cut stumps to prevent re-sprouting. Felled materials were stacked on the edge of the cleared area and burnt on site. Follow-up treatments were applied every four to six months for three years after the initial clearing with the purpose of removing all alien saplings. A survey by Ruwanza et al. (in press) on both CCS and TS shows that both sites are showing signs of recovery with indigenous vegetation e.g. Kiggelaria africana, Olea europaea and Searsia angustifolia existing.

For each of the above-mentioned restoration treatments, three sites where selected along the dry zone of the river. At each site, a 20-metre transect (parallel to the river, with the first transect point being underneath the tree canopy) was established comprising 5 soil core collecting points spaced $5 \mathrm{~m}$ apart, this provided 60 samples per sampling month. Soils were collected at a depth of 5$10 \mathrm{~cm}$ (after removal of the overlaying debris) monthly during the three summer months of January, February and March of 2011. Our decision to collect soils at the abovementioned depth was based on site observations which showed that the soil and biomass top layer extended for $2-5 \mathrm{~cm}$ into the soil layer. Our observation is in accordance with Behera and Sahani (2003) who showed that Eucalyptus plantations have a soil and biomass organic horizon of approximately $10 \mathrm{~cm}$. It was acknowledged a priori that soil water repellency is likely to occur during the above-mentioned three summer months (hottest months) as compared to other months of the year which have the potential to receive some rain in Western Cape Province of South Africa. After soil collection, soil moisture, soil water repellency and soil infiltration were assessed under laboratory conditions. In February 2011 three samples per restoration treatment were randomly sampled for soil texture, soil $\mathrm{pH}$ and soil carbon (\%). Soil pH was measured in 1:5 soil-KCl extract (Rhoades, 1982), whilst, soil carbon was analysed using a modified Walkley Black method as described by Chan et al. (2001).

\subsection{Gravimetric soil moisture measurements}

Soil moisture was assessed in terms of gravimetric soil moisture expressed in percentage (\%). The sixty soil cores collected in bags from the four different restoration treatments were weighed wet, dried in a drying oven at $60{ }^{\circ} \mathrm{C}$ for $48 \mathrm{~h}$, then re-weighed to obtain the water content (Black, 1965). This method was used because during the dry season the ground is hard and not receptive to soil moisture metre probes.

Table 1

Characteristics of the study area. The mean soil carbon (\%) and soil pH were derived from randomly selected soil samples (three samples per restoration type) collected during February 2011.

\begin{tabular}{|c|c|c|c|c|c|c|}
\hline Restoration type & Site name & Coordinates & Soil texture ${ }^{a}$ & Soil carbon (\%) & Soil pH & Dominant plant species \\
\hline \multirow[t]{3}{*}{$\begin{array}{l}\text { Completely cleared } \\
\text { sites }\end{array}$} & Site 1 & $33^{\circ} 27^{\prime} 35.89^{\prime \prime} \mathrm{S}, 18^{\circ} 57^{\prime} 07.35^{\prime \prime} \mathrm{E}$ & Sandy loam & 1.06 & 4.37 & $\begin{array}{l}{ }^{\mathrm{Y}} \text { Kiggelaria africana L., }{ }^{\mathrm{Y}} \text { Diospyros glabra (L.) De Winter, } \\
{ }^{\mathrm{Y}} \text { Rhus angustifolia L., Zantedeschia aethiopica }\end{array}$ \\
\hline & Site 2 & $33^{\circ} 27^{\prime} 43.60^{\prime \prime} \mathrm{S}, 18^{\circ} 57^{\prime} 12.05^{\prime \prime} \mathrm{E}$ & Sandy loam & 2.59 & 4.5 & $\begin{array}{l}\text { Y Kiggelaria africana L., ' Diospyros glabra (L.) De Winter, } \\
{ }^{Y} \text { Rhus angustifolia L., Zantedeschia aethiopica (L.) Spreng, }\end{array}$ \\
\hline & Site 3 & $33^{\circ} 27^{\prime} 54.21^{\prime \prime} \mathrm{S}, 18^{\circ} 56^{\prime} 31.28^{\prime \prime} \mathrm{E}$ & Sandy loam & 2.57 & 4.93 & $\begin{array}{l}{ }^{\mathrm{Y}} \text { Kiggelaria africana L., }{ }^{\mathrm{Y}} \text { Diospyros glabra (L.) De Winter, } \\
\mathrm{Y}_{\text {Rhus angustifolia L., Zantedeschia aethiopica (L.) Spreng, }}\end{array}$ \\
\hline \multirow[t]{3}{*}{ Invaded sites } & Site 1 & $33^{\circ} 26^{\prime} 58.56^{\prime \prime} \mathrm{S}, 18^{\circ} 57^{\prime} 11.47^{\prime \prime} \mathrm{E}$ & Sandy loam & 1.76 & 4.4 & ${ }^{\mathrm{M}}$ Eucalyptus camaldulensis \\
\hline & Site 2 & $33^{\circ} 28^{\prime} 09.41^{\prime \prime} \mathrm{S}, 18^{\circ} 56^{\prime} 18.98^{\prime \prime} \mathrm{E}$ & Sandy loam & 2.20 & 4.57 & ${ }^{\mathrm{M}}$ Eucalyptus camaldulensis \\
\hline & Site 3 & $33^{\circ} 36^{\prime} 14.04^{\prime \prime} \mathrm{S}, 18^{\circ} 58^{\prime} 24.45^{\prime \prime} \mathrm{E}$ & Sandy loam & 1.78 & 4.43 & ${ }^{\mathrm{M}}$ Eucalyptus camaldulensis \\
\hline \multirow[t]{3}{*}{ Thinned sites } & Site 1 & $33^{\circ} 26^{\prime} 49.05^{\prime \prime} \mathrm{S}, 18^{\circ} 57^{\prime} 23.63^{\prime \prime} \mathrm{E}$ & Sandy loam & 2.36 & 4.93 & $\begin{array}{l}{ }^{\mathrm{I}} \text { Eucalyptus camaldulensis, 'Acacia mearnsii, 'Kiggelaria africana L., } \\
{ }^{\mathrm{I}} \text { Rubus cuneifolius Pursh, 'Rhus angustifolia L. }\end{array}$ \\
\hline & Site 2 & $33^{\circ} 28^{\prime} 00.56^{\prime \prime} \mathrm{S}, 18^{\circ} 56^{\prime} 23.98^{\prime \prime} \mathrm{E}$ & Sandy loam & 0.91 & 4.8 & $\begin{array}{l}\text { IEucalyptus camaldulensis, 'Acacia mearnsii, IKiggelaria africana L., } \\
{ }^{\text {I} R u b u s ~ c u n e i f o l i u s ~ P u r s h, ~ ' R h u s ~ a n g u s t i f o l i a ~ L . ~}\end{array}$ \\
\hline & Site 3 & $33^{\circ} 33^{\prime} 50.58^{\prime \prime} \mathrm{S}, 18^{\circ} 56^{\prime} 56.28^{\prime \prime} \mathrm{E}$ & Sandy loam & 1.19 & 4.67 & $\begin{array}{l}\text { IEucalyptus camaldulensis, }{ }^{\mathrm{I}} \text { Acacia mearnsii, }{ }^{\mathrm{I}} \text { Kiggelaria africana L., } \\
{ }^{\mathrm{I}} \text { Rubus cuneifolius Pursh, }{ }^{\mathrm{I}} \text { Rhus angustifolia L. }\end{array}$ \\
\hline \multirow[t]{3}{*}{ Natural sites } & Site 1 & $33^{\circ} 26^{\prime} 46.83^{\prime \prime} \mathrm{S}, 18^{\circ} 57^{\prime} 27.72^{\prime \prime} \mathrm{E}$ & Sandy loam & 1.30 & 4.93 & $\begin{array}{l}{ }^{\mathrm{M}} \text { Kiggelaria africana L., }{ }^{\mathrm{M}} \text { Diospyros glabra (L.) De Winter, } \\
{ }^{\mathrm{M}} \text { Rhus angustifolia L., }{ }^{\mathrm{M}} \text { Podocarpus elongatus (Ait.) L'Herit. ex Pers. }\end{array}$ \\
\hline & Site 2 & $33^{\circ} 28^{\prime} 18.48^{\prime \prime} \mathrm{S}, 18^{\circ} 56^{\prime} 19.32^{\prime \prime} \mathrm{E}$ & Sandy loam & 2.07 & 4.43 & $\begin{array}{l}{ }^{\mathrm{M}} \text { Kiggelaria africana L., }{ }^{\mathrm{M}} \text { Diospyros glabra (L.) De Winter, } \\
{ }^{\mathrm{M}} \text { Rhus angustifolia L., }{ }^{\mathrm{M}} \text { Podocarpus elongatus (Ait.) L'Herit. ex Pers. }\end{array}$ \\
\hline & Site 3 & $33^{\circ} 27^{\prime} 26.46^{\prime \prime} \mathrm{S}, 18^{\circ} 56^{\prime} 59.60^{\prime \prime} \mathrm{E}$ & Sandy loam & 2.66 & 4.7 & $\begin{array}{l}{ }^{\mathrm{M}} \text { Kiggelaria africana L., }{ }^{\mathrm{M}} \text { Diospyros glabra (L.) De Winter, } \\
{ }^{\mathrm{M}} \text { Rhus angustifolia L., }{ }^{\mathrm{M}} \text { Podocarpus elongatus (Ait.) L'Herit. ex Pers. }\end{array}$ \\
\hline
\end{tabular}

M - Mature tree stands, I - Intermediate tree stands, Y - Young tree stand.

a Textural classes according to handbook of standard soil testing methods (1990) for advisory purposes. Compiled by the non-affiliated soil analysis work committee, Soil Science Society of South Africa. 


\subsection{Soil repellency measurements}

Soil water repellency was measured using both the Water Droplet Penetration Time (WDPT) method (Doerr and Thomas, 2000; Scott, 1993) and the Critical Surface Tension (CST) method (Scott, 2000). Soils separate from the ones used to measure soil moisture were first passed gently through a $2 \mathrm{~mm}$ sieve and air-dried. Sieving was adopted to remove organic material and rocks that could increase water repellency if not removed. Air drying as opposed to oven drying was adopted to avoid a heat-induced artificial enhancement of repellency and an artificial reduction in soil moisture content at the beginning of the experiment (Doerr and Thomas, 2000). Air drying was done in the laboratory at temperatures of about $22^{\circ} \mathrm{C}\left( \pm 2{ }^{\circ} \mathrm{C}\right)$ - similar to average Western Cape summer temperatures.

After drying, samples were placed in petri dishes, levelled, and kept at standard laboratory conditions. The WDPT test, which measures how long repellency persists on a porous surface, was conducted by placing a water drop on the soil surface and recording the time taken for the water to penetrate the soil. Five drops of distilled water were applied with a hypodermic syringe to the surface of soil samples. The penetration time for each drop was recorded and the average penetration time taken as representative of the WDPT for each sample. In this study, soil samples were classified as wettable when the water drop infiltrated within $5 \mathrm{~s}$, slightly water repellent (5-60 s), strongly water repellent (60-600 s), severely water repellent (600-3600 s) and extremely water repellent (>3600 s) according to Bisdom et al. (1993).

To measure CST, we used different soil samples that were collected at the same sampling point along the Berg River and these soils were subjected to the same drying and sieving methods as described above. The critical surface tension (CST) uses the known surface tensions of standardized solutions of ethanol in water (Scott, 2000) to measure water repellency severity. We used a range of aqueous ethanol solutions of varying molarities (Table 2); drops of those dilutions were applied to a soil surface and their infiltration behaviour was observed (Leighton-Boyce et al., 2005). To facilitate description and data analysis, repellency severity is divided into 12 nominal classes (see Leighton-Boyce et al., 2005), where Class 1 denotes wettable (0\% Ethanol) and Class 12 denotes the highest repellency severity ( $>50 \%$ ethanol). A droplet with a higher surface tension than that of the soil surface will remain on it for some time, whereas a droplet with a lower surface tension will infiltrate instantly. In this study, five drops of prepared solutions were applied onto the soil surface using a hypodermic syringe. Increasing ethanol concentrations (Table 2) were used until drop penetration (at least three of the five drops) occurred within $3 \mathrm{~s}$; that concentration of ethanol was taken as indicative of the repellency severity at that point (Scott, 2000).

\subsection{Infiltration measurements}

To simulate infiltration, soils collected from the same above mentioned sampling points along the Berg River were exposed to water then left for a maximum of 14 days during which their infiltration status was determined (Doerr and Thomas, 2000). Twenty grammes of sieved and air-dried soil was placed in clear plastic petri-dishes (50 mm radius and $10 \mathrm{~mm}$ depth) and $16 \mathrm{ml}$ of distilled water was carefully added to the smooth soil surface in a way that allowed complete cover of the soils by water. The samples were then covered with lids to prevent evaporation, whilst the clear dishes allowed visual determination of the progress of infiltration. This method adopted from Doerr and Thomas (2000) allowed a distinction to be made between (1) saturated samples where continuous water was visible at the bottom of the sample indicating complete infiltration, (2) moist samples where some pore spaces were filled with water and (3) dry samples where no infiltration could be observed. Although this method is subjective, it was preferred as it resulted in no physical disturbance to the sample.

After completion of 14 days, with infiltration checked after $1 \mathrm{~h}$, $2 \mathrm{~h}, 1 \mathrm{st}$ day, 5th day and 14th day, soil samples were left to dry for 14 more days by uncovering the dishes and allowing air-drying to take place. After 14 days, the WDPT test was carried out at the sample soil surface in areas that had been covered by water.

\subsection{Statistical analysis}

The gravimetric soil moisture levels and repellency scores for the different soils were analysed by ANOVA using STATISTICA version 10 (Statsoft Inc, 2010). Assumptions of normality were tested using both the Shapiro-Wilk and Kolmogorov-Smirnov tests. Since most of the variables did not satisfy these assumptions, alternative non-parametric tests (Mann-Whitney U-test and Kruskal-Wallis ANOVA) were used. The above-mentioned non-normality of data is in agreement with Scott (2000), who showed that analyses based in the WDPT method are strongly bimodal and non-normal. In this regard, the Spearman rank correlation coefficients (Rspm) were calculated to examine the linear relationships between soil moisture and water repellency.

\section{Results}

\subsection{Gravimetric soil moisture}

Results of the Kruskal-Wallis test (for all the three measured months) show significantly lower gravimetric soil moisture (\%) levels in completely cleared sites and thinned sites compared to natural sites (Fig. 2). Gravimetric soil moisture (\%) levels were lower in completely cleared sites compared to natural sites and these differences were of greater magnitude during the month of January $(\mathrm{H}(1)=17.3768, P=0.001)$ than in February $(\mathrm{H}(1)=10.0684, P=$ $0.015)$ and March $(H(1)=12.2843, P=0.005)$. Similarly, significantly lower gravimetric soil moisture (\%) levels in thinned sites compared to natural sites were found in all the three measured months. The magnitude of difference was greater in January (mean 2.46 compared to $7.22, P \leq 0.001$ ) than in February (1.96 compared to 5.19, $P \leq 0.001$ ) and March (mean 1.67 compared to $4.47, P \leq 0.01$ ). There were no significant $(P \geq 0.05)$ gravimetric soil moisture differences between invaded sites and natural sites during all the three measured months.

\subsection{Water repellency}

\subsubsection{Water droplet penetration time}

Nine $(60 \%)$ of the 15 air-dried samples collected in January and in February and 12 samples (80\%) of the 15 samples collected in March 2011 at the natural sites were wettable with WDPT values of less than $5 \mathrm{~s}$, whereas the remaining samples exhibited only slight water repellency with WDPT values between 5 and 60 s (Fig. 3). Eight (53\%) of

Table 2

Ethanol concentrations (\% volume), respective surface tensions, and associated descriptive soil water repellency categories used in this study (adopted from Leighton-Boyce et al., 2005).

\begin{tabular}{|c|c|c|c|c|c|c|c|c|c|c|c|c|}
\hline Ethanol concentration (\%) & 0 & 1 & 2 & 3 & 5 & 8.5 & 13 & 18 & 24 & 36 & 50 & $>50$ \\
\hline 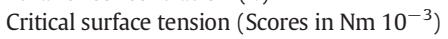 & 72.1 & 66.9 & 63.9 & 60.9 & 56.6 & 51.2 & 46.3 & 42.2 & 38.6 & 33.1 & 31.0 & $<31.0$ \\
\hline Descriptive category & Wettable & \multicolumn{3}{|c|}{ Low repellency } & \multicolumn{3}{|c|}{ Moderate repellency } & Sever & lency & \multicolumn{3}{|c|}{ Extreme repellency } \\
\hline
\end{tabular}




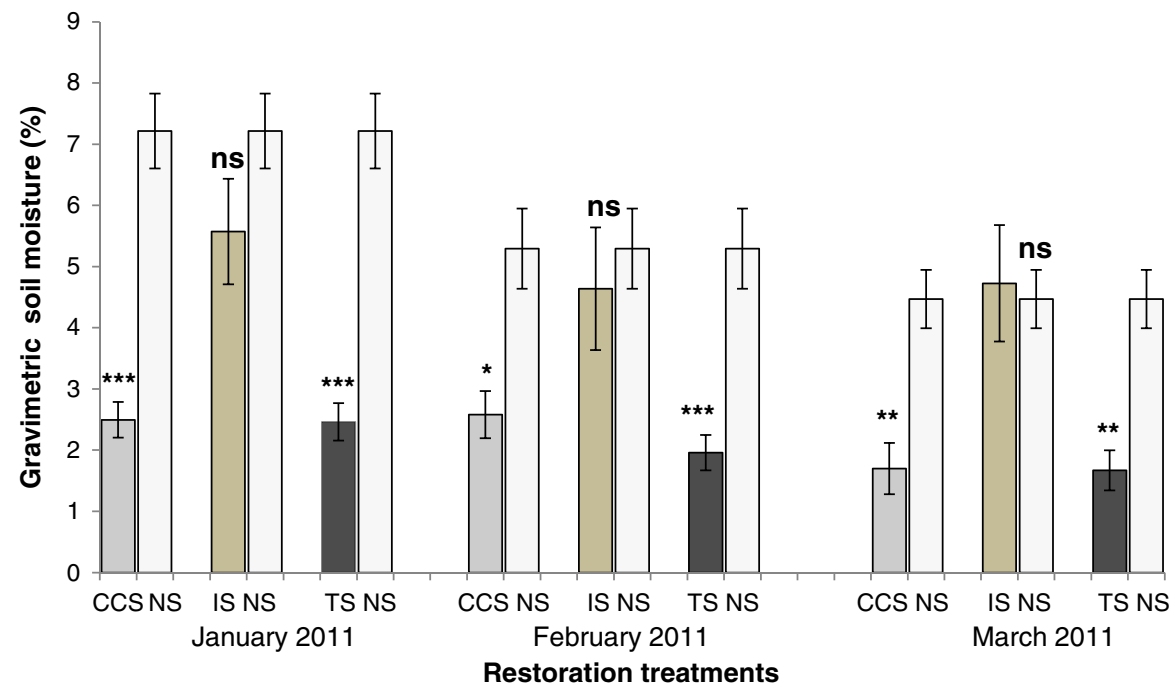

Fig. 2. Gravimetric soil moisture (\%) levels in soil samples taken at a depth of $5-10 \mathrm{~cm}$ from completely cleared sites (CCS), invaded sites (IS), thinned sites (TS) and natural sites (NS). Bars represent mean \pm standard error at the $95 \%$ confidence interval. Kruskal-Wallis ANOVA test showing significant effects at ${ }^{* * *} \mathrm{P} \leq 0.001{ }^{* *} \mathrm{P} \leq 0.01$ and ${ }^{*} \mathrm{P} \leq 0.05$. NS $=$ not significant.

the 15 air-dried samples collected in the invaded sites in January as well as in February and 12 (80\%) of the 15 samples collected in March were wettable; whereas the other samples exhibited slight to severe water repellency. In the thinned sites eight (53.3\%) of the 15 air-dried samples collected in January, nine (60\%) of the 15 samples collected in February and six (40\%) of the 15 samples collected in February exhibited slight to strong soil water repellency. It is remarkable that in all three sampling months less wettable samples were detected in the thinned sites in comparison with the other three sites. It is noteworthy that all samples taken in the completely cleared sites in January, February and March were all wettable, with WDPT values on the air-dried samples of less than $5 \mathrm{~s}$ (Fig. 3).

\subsubsection{Critical surface tension}

CST scores indicate that soil water repellency increases with Eucalyptus invasion from severe repellency in invaded sites to low and moderate repellency in thinned sites. In completely cleared sites and natural sites, results of CST indicated low to wettable soil water repellency (Fig. 4). Significant differences were noted between invaded and natural sites in all the three measured months (January $\mathrm{H}(1)=8.1721, P=0.0043$; February $\mathrm{H}(1)=10.9854, P=0.009$ and March $H(1)=8.8702, P=0.0029)$. However, differences between invaded sites and thinned sites were only statistically significant in February $(\mathrm{H}(1)=4.7102, P=0.051)$.

\subsection{Infiltration rates}

All soils whose WDPT resembled a slight to severe soil water repellent status (i.e. soils in invaded and thinned sites) became fully saturated (all pores filled) in approximately one day during the study period with the exception of thinned sites during the month of January which took 5 days to attain complete infiltration (Table 3 \& Fig. 5). This indicates that the observed slight to severe soil water repellent status in invaded soils did not induce resistance to infiltration. After 14 days of drying, all the soils in all the restoration treatments had a WDPT of less than $5 \mathrm{~s}$, implying that they were wettable thus the slight to severe soil water repellent status was not restored after 14 days (Table 3 ).

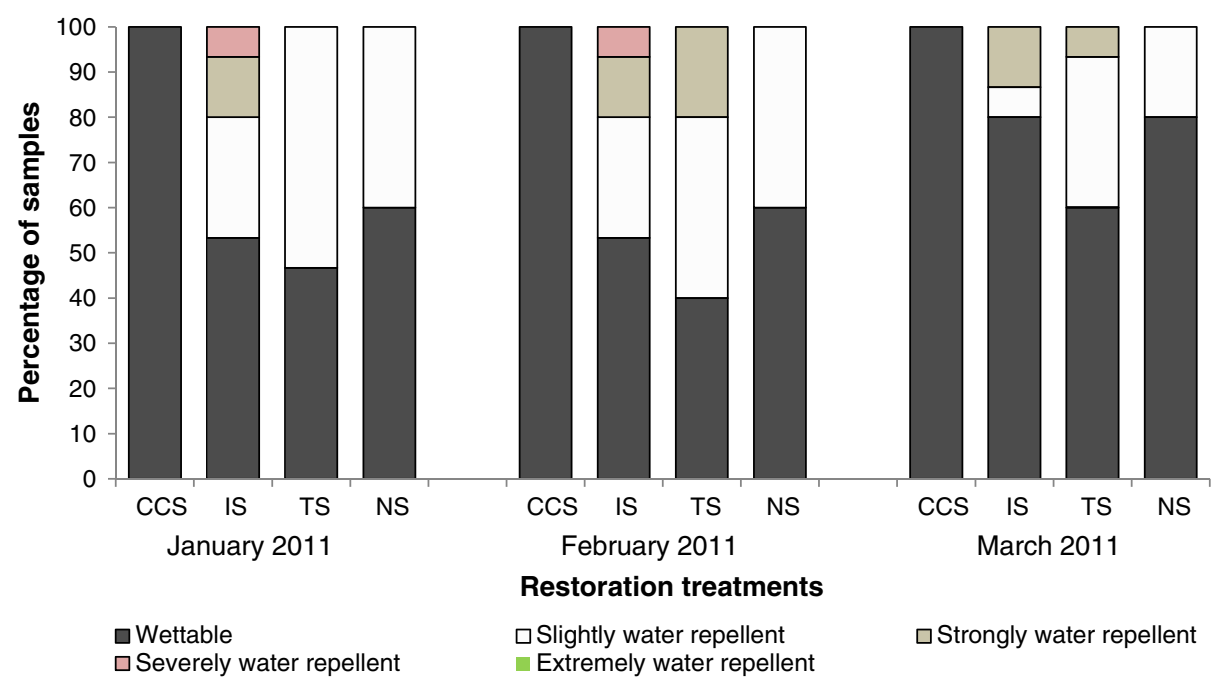

Fig. 3. Distribution of water repellency classes (WDPT) in soil samples taken at a depth of $5-10 \mathrm{~cm}$ from completely cleared sites (CCS), invaded sites (IS), thinned sites (TS) and natural sites (NS). 


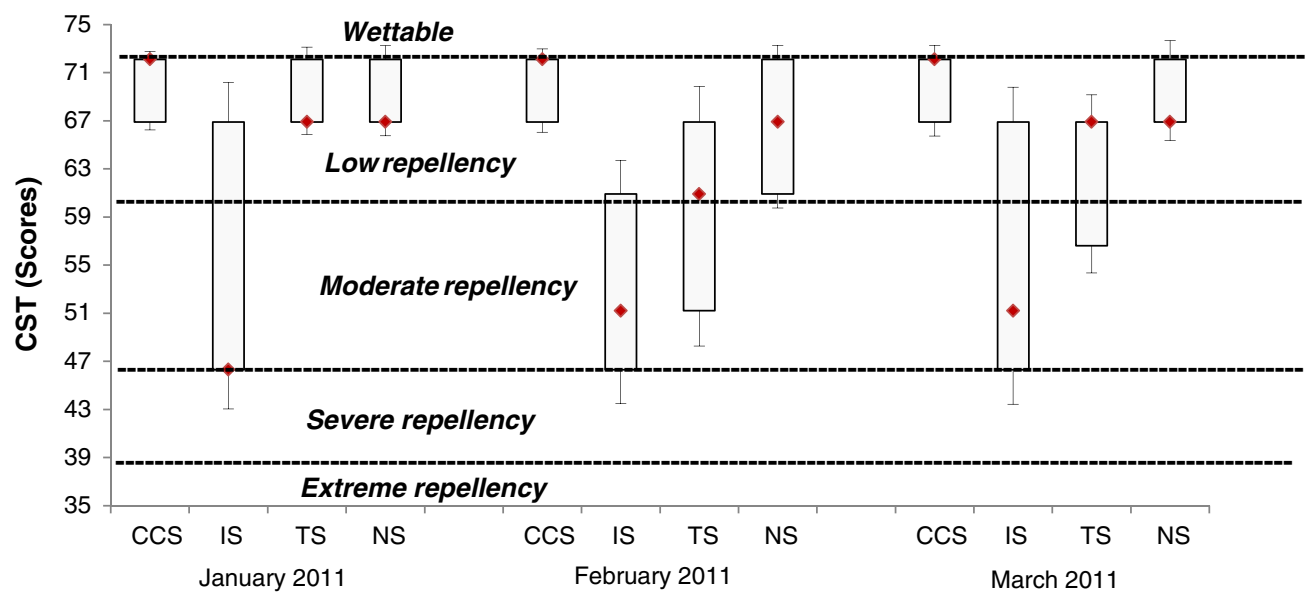

Restoration treatments

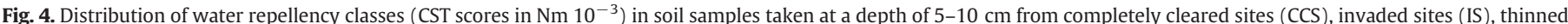
sites (TS) and natural sites (NS). Boxes define the 25 th and 75 th percentile positions; $(\downarrow)$ inside the box shows the median score and the whiskers the 10 th and 90 th percentiles.

\section{Discussion}

The invasion of the Berg River by Eucalyptus camaldulensis has induced several changes to the soils, including increased soil moisture, the intensification of soil water repellency and changes to soil water infiltration capacity. That soils under Eucalyptus stands generally exhibit higher soil moisture levels compared to soils where Eucalyptus has been thinned or completely removed is in agreement with the findings of Ashwani-Kumar et al. (1995) and Srivastava et al. (2003). Both studies investigated variations in soil moisture under Eucalyptus species of different age groups at different soil depths (Srivastava et al., 2003) as well as soil moisture under Eucalyptus species compared to other tree species e.g. E. tereticornis, Acacia nilotica, Prosopis juliflora and Dalbergia sissoo (Ashwani-Kumar et al., 1995). They concluded that soil moisture levels under Eucalyptus species were extremely high compared to those under other species and in those of open areas (control sites). Reasons for high soil moisture levels in soils underneath Eucalyptus stands could be linked to higher Eucalyptus stand density (Poore and Fries, 1985) which has the potential to alter infiltration and evapotranspiration (Butcher, 1977). Furthermore Ashwani-Kumar et al. (1995) found that soils underneath eucalypts species generally have higher water holding capacity than soils underneath other plants. The high water holding capacity of soils under Eucalyptus stands could be a result of hydraulic redistribution which has been observed in Eucalyptus species especially E. kochii subsp. borealis (Brooksbank et al., 2011). Hydraulic redistribution is described as transport of water via roots along water potential gradients from wetter to drier parts of the soil profile (Brooksbank et al., 2011). Bouillet et al. (2002) noticed that tap roots of Eucalyptus species can descend to a depth of $3 \mathrm{~m}$ and the lateral roots can spread up to $2.5 \mathrm{~m}$ thereby allowing access to water from the water table.

Increased litter levels, mainly associated with Eucalyptus species, can also increase soil moisture levels by providing soil cover which facilitates the capture and infiltration of rainwater as well as dew especially during dry seasons (Dormaar and Carefoot, 1996). Besides increased litter levels the canopy of both Eucalyptus and native species (particularly in natural sites) provides shelter where soil moisture becomes higher and/or maintained upon capture by litter (Dormaar and Carefoot, 1996; Srivastava et al., 2003) compared to areas where the canopy has been removed (cleared sites), this can explain the reduced soil moisture levels in cleared and thinned sites.

Despite the increased soil moisture levels recorded in Eucalyptus invaded sites, soil water repellency measured both by the WDPT and the CST methods gradually increased with invasion and/or restoration treatment varying from severely repellent in invaded sites to slightly repellent in thinned sites and wettable in completely cleared sites. This shows that vegetation was the primary determinant of water repellency, a result consistent with observations by Scott (2000)

Table 3

Observed infiltration status (percentage of samples) of $16 \mathrm{ml}$ water added to $20 \mathrm{~g}$ soil samples (60 soil samples per sampling month) for the period of 14 days during the months of January to March and the associated WDPT (s) recorded in different restoration treatments namely completely cleared sites (CCS), invaded sites (IS), thinned sites (TS) and natural sites (NS).

\begin{tabular}{|c|c|c|c|c|c|c|c|c|c|c|c|c|c|c|c|c|c|c|}
\hline & \multirow{3}{*}{ Restoration treatments } & \multirow{3}{*}{$\frac{\text { Before infiltration }}{\text { WDPT }}$} & \multicolumn{15}{|c|}{ Infiltration phase } & \multirow{3}{*}{$\frac{\text { After drying }}{\text { WDPT }}$} \\
\hline & & & \multicolumn{3}{|l|}{$1 \mathrm{~h}$} & \multicolumn{3}{|l|}{$2 \mathrm{~h}$} & \multicolumn{3}{|l|}{1 day } & \multicolumn{3}{|c|}{5 days } & \multicolumn{3}{|c|}{14 days } & \\
\hline & & & 1 & 2 & 3 & 1 & 2 & 3 & 1 & 2 & 3 & 1 & 2 & 3 & 1 & 2 & 3 & \\
\hline \multirow[t]{4}{*}{ January } & CCS & $<5$ & 60 & 40 & 0 & 100 & 0 & 0 & 100 & 0 & 0 & 100 & 0 & 0 & 100 & 0 & 0 & $<5$ \\
\hline & IS & $>5$ & 33.3 & 53.3 & 13 & 66.6 & 26.6 & 6.6 & 86.6 & 13.3 & 0 & 100 & 0 & 0 & 100 & 0 & 0 & $<5$ \\
\hline & TS & $>5$ & 80 & 20 & 0 & 80 & 20 & 0 & 80 & 20 & 0 & 100 & 0 & 0 & 100 & 0 & 0 & $<5$ \\
\hline & NS & $<5$ & 46.6 & 53.3 & 0 & 73.3 & 26.6 & 0 & 100 & 0 & 0 & 100 & 0 & 0 & 100 & 0 & 0 & $<5$ \\
\hline \multirow[t]{4}{*}{ February } & CCS & $<5$ & 46.6 & 53.3 & 0 & 100 & 0 & 0 & 100 & 0 & 0 & 100 & 0 & 0 & 100 & 0 & 0 & $<5$ \\
\hline & IS & $>5$ & 33.3 & 53.3 & 13.3 & 80 & 20 & 0 & 93.3 & 6.6 & 0 & 100 & 0 & 0 & 100 & 0 & 0 & $<5$ \\
\hline & TS & $>5$ & 60 & 40 & 0 & 100 & 0 & 0 & 100 & 0 & 0 & 100 & 0 & 0 & 100 & 0 & 0 & $<5$ \\
\hline & NS & $<5$ & 46.6 & 53.3 & 0 & 73.3 & 26.6 & 0 & 100 & 0 & 0 & 100 & 0 & 0 & 100 & 0 & 0 & $<5$ \\
\hline \multirow[t]{4}{*}{ March } & CCS & $<5$ & 60 & 40 & 0 & 93.3 & 6.6 & 0 & 100 & 0 & 0 & 100 & 0 & 0 & 100 & 0 & 0 & $<5$ \\
\hline & IS & $>5$ & 33.3 & 66.6 & 0 & 86.6 & 13.3 & 0 & 100 & 0 & 0 & 100 & 0 & 0 & 100 & 0 & 0 & $<5$ \\
\hline & TS & $>5$ & 80 & 20 & 0 & 93.3 & 6.6 & 0 & 100 & 0 & 0 & 100 & 0 & 0 & 100 & 0 & 0 & $<5$ \\
\hline & NS & $<5$ & 66.6 & 33.3 & 0 & 93.3 & 6.6 & 0 & 100 & 0 & 0 & 100 & 0 & 0 & 100 & 0 & 0 & $<5$ \\
\hline
\end{tabular}

1 - All pores filled, 2 - Some pores filled, 3 - No infiltration. 
A

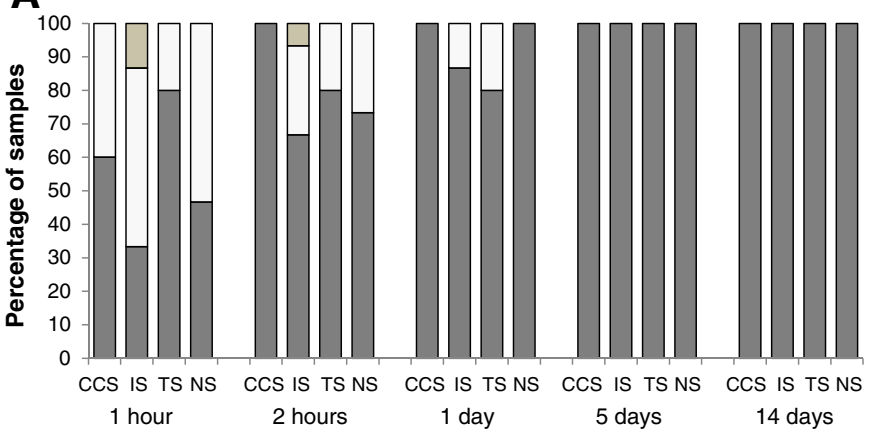

Restoration treatments

B

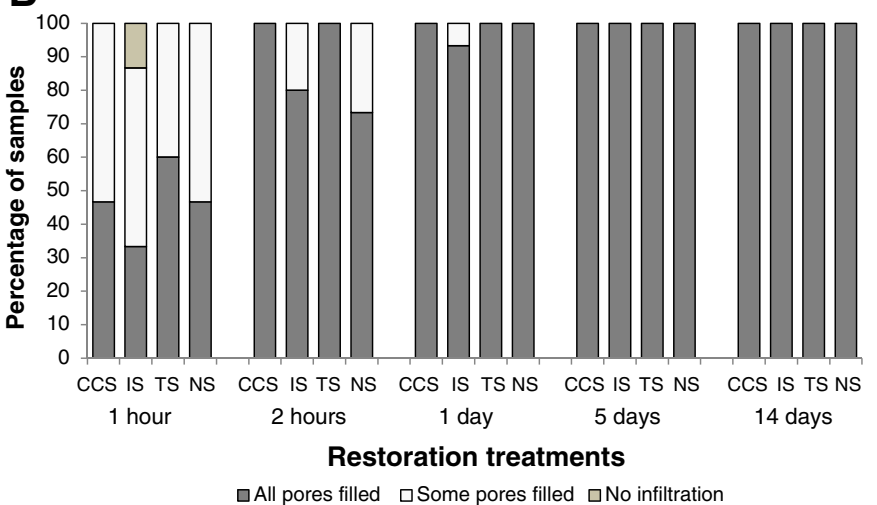

C

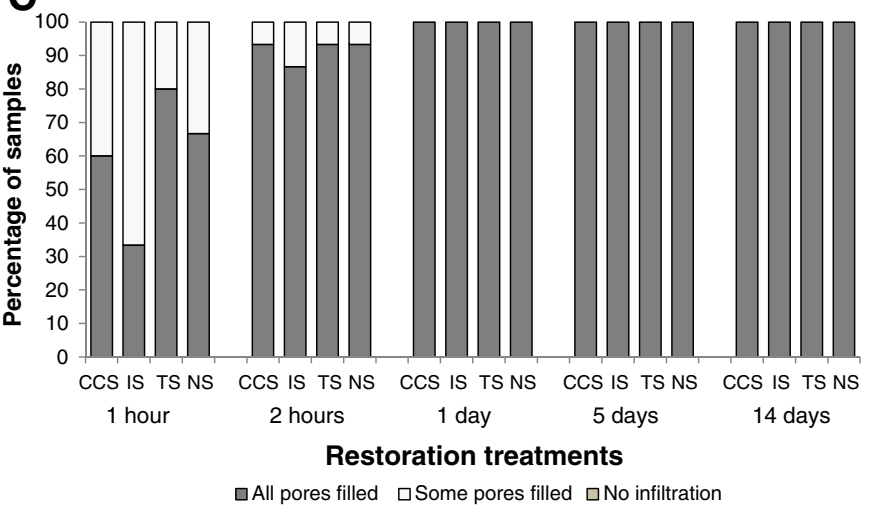

Fig. 5. Results of water infiltration on soil samples taken at a depth of 5-10 cm from completely cleared sites (CCS), invaded sites (IS), thinned sites (TS) and natural sites (NS) for the months of January (A), February (B) and March (C)

and Coelho et al. (2005). One of the reasons for increased repellency under Eucalyptus stands is the increase in debris and organic matter from dead Eucalyptus leaves (Eynard et al., 2004). Eucalypts are known for the high levels of phenolic acids and volatile oils in their leaves (Sasikumar et al., 2002) which produce organic leachates that can induce repellency in soils (Scott, 2000). In addition, excessive heat and dryness (associated with high evapotranspiration) during summer contribute to the volatilization of the released hydrophobic organic substances and allow them to condense on the top soils, creating a repellent surface (Malkinson and Wittenberg, 2011); this is also exacerbated by fire (Doerr et al., 2005).

Soil mineral properties have also been demonstrated to determine soil water repellency properties. Soil clay content and soil type can significantly affect soil response to heating, and consequently level of repellency (Malkinson and Wittenberg, 2011). However, it has been suggested that formation of water repellency may depend on other soil properties, such as grain size distribution (DeBano, 1991), organic matter to clay content ratio and the mineralogy of the clays (Mataix-Solera et al., 2008). In general it is believed that sandy soils, like the ones on our study sites, are more likely to be repellent than clay soils (DeBano, 1991).

We have shown that soil repellency decreases after clearing of Eucalyptus. The resultant non-repellency in cleared and thinned soils is probably associated with the absence of hydrophobic organic substances. Indeed, studies have reported that the concentration of repellency decreases with the efficiency of decomposition of organic substances (Valat et al., 1991) though the time taken for the decomposition process to result in non-repellency soils still remains largely untested. Apart from the absence of hydrophobic organic substances, reduced soil moisture levels in cleared and thinned sites could also explain the lack of soil repellency mainly due to the absence/lack of microbial biomass that favours moist area. Research has identified both fungi and bacteria as the dominant microbial groups that contribute to soil repellency (Hallett et al., 2004). They produce large quantities of potentially hydrophobic material (as defence mechanism) and it is these materials that contribute to repellency (Hallett et al., 2004). Though microbial biomass was not tested in this study, research in South Africa's Fynbos biome has shown a strong, correlation between both bacterial as well as fungal diversity and the plant community (Slabbert et al., 2010). Slabbert et al. (2010) found the lowest fungal diversity during the month of February (one of our measured summer months) at Kalbaskraal (a site being rehabilitated following invasion of the alien tree Acacia saligna) compared to the highest fungal diversity at Riverlands (a conservation area with no alien species).

Infiltration data suggest that soil water repellency did not reduce the rate of infiltration into the soil surface particularly on soils that were repellent (i.e. soils from Eucalyptus invaded sites). This contradicts previous reports that soil water repellency helps to reduce runoff generation time and increases the runoff rates, which in turn have other important consequences such as increased erosion risk, irregularity in the wetting front and the development of preferential flow paths, as well as rapid washing of nutrients and agrochemicals (Coelho et al., 2005). The above-mentioned results support the finding that water repellency is a marginal factor in overland flow and soil erosion generation processes under invaded stands (Coelho et al., 2005; Doerr and Thomas, 2000).

Ziogas et al. (2005) have shown that soil water repellency should preferably be measured on samples taken in the field under dry conditions in order to reveal and determine the highest persistence of soil water repellency that might occur in the field. However, our results from the laboratory could still show that soils became non-repellent after wetting and drying. These results suggest that re-establishment of soil water repellency after infiltration is not a result of soil moisture loss. This concurs with results by Doerr and Thomas (2000) who suggested that, after wetting, re-establishment of repellency may require a fresh input of water-repellent substances. It is difficult to suggest which fresh inputs will be required to re-establish repellency, but heat/fire and litter might be important factors that trigger repellency, emanating from conclusions by Ma'shum and Farmer (1985) who showed that oven-drying of thoroughly wetted soils can re-establish repellency to some extent, although not to its initial levels.

\section{Implication for restoration}

This study conceptualizes soil water repellency in relation to the clearing of invasive trees for the purpose of vegetation restoration (Fig. 6). Both the WDPT and CST methods show that soil water repellency is associated with Eucalyptus invasion along the Berg River and that removal of invasive stands can restore soils to a non-repellent state. Our results confirm that soil water repellency is not a soil legacy effect that hinders native species recovery. Therefore, alien 


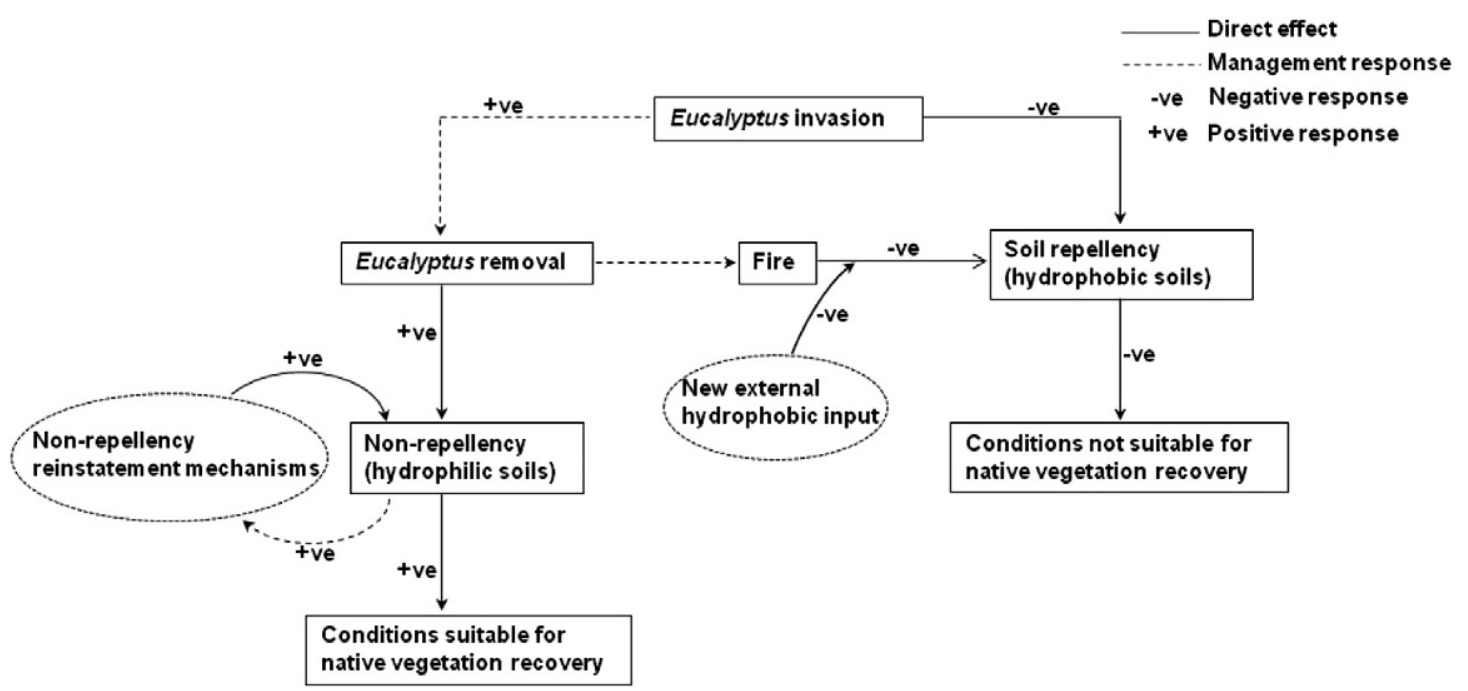

Fig. 6. Conceptualization of changes in soil water repellency in relation to restoration of riparian plant communities along the Berg River. Invasion by alien trees has the potential to enhance soil water repellency thus creating unsuitable conditions for native vegetation recovery. Removal of invasive trees and other interventions can reduce repellency, thus facilitating recovery of native vegetation. See the Discussion for elucidation.

removal can restore soils to a non-repellent state that could improve soil related ecosystem functions e.g. soil biology (macro and micro organisms), soil chemistry (nutrient cycling and organic matter) and soil physical properties (structure and texture), which will help towards restoring indigenous vegetation composition, structure and species richness. From a management point of view the lack of repellency reinstatement after soil wetting mainly caused by water introduction should be maintained if restoration of cleared sites is to be achieved. Non-repellency can be maintained by tilling cleared sites (Hallett, 2007), applying soil surfactants on cleared sites either as liquid through irrigation or as granular material through fertigation (Moore et al., 2010) or overlaying cleared sites with a clay rich soil layer (Wallis and Horne, 1992) transferred from adjacent natural vegetation also called soil transfer (Hölzel and Otte, 2003). The abovementioned methods are known for increasing the surface area of soils thereby removing hydrophobic coating from soil surfaces (Hallett et al., 2004); however they may be expensive from a restoration point of view.

Given that our results showed that soil water repellency in invaded and thinned sites had no impact on soil infiltration, we suggest that the recovery of native species after clearing will not necessarily be hampered by overland flow or soil erosion. Although erosion could still occur and hinder native species recovery (after Eucalyptus removal), other reasons for the lack of native species could be a decrease in native soils' seed bank as well as poor native species dispersal and recruitment (Holmes et al., 2005) the later related to unsuitable germination and establishment conditions. Lastly, the lack of soil moisture on cleared sites, particularly during the dry months, can be overcome by sowing drought tolerant or deep-rooted native species that have the potential to draw ground or river water.

Future studies that seek to show the effect of soil water repellency on native species recovery, or any soil water repellency study, should consider doing both field and laboratory based studies simultaneously. Although, Ziogas et al. (2005) have shown that measuring soil water repellency under field conductions shows better results, we suggest that conducting both field and laboratory studies simultaneously would show more realistic and accurate results.

\section{Acknowledgements}

This work was funded by DST-NRF Centre of Excellence for Invasion Biology (CIB) and the Working for Water Programme through their collaborative research project on "Research for Integrated Management of Invasive Alien Species". SR thanks the Oppenheimer Memorial Trust for additional funding (OMT Ref. 19351/01). We thank: two anonymous referees for valuable comments; the farmers around the upper Berg River catchment for permission to work on their land; Manfred Paulsen (WfW implementation manager), Suzaan Kritzinger-Klopper (Senior Technical Officer of the CIB) for technical support and assistance in liaising with landowners, and Farai Tererai for general assistance. DMR acknowledges support from the National Research Foundation.

\section{References}

Ashwani-Kumar, A.M., Srivastava, R.J., Dixit, R.K., 1995. Variation in soil moisture regime under various tree species during the summer season. Van Anusandhan 2, 29-38.

Behera, N., Sahani, U., 2003. Soil microbial biomass and activity in response to Eucalyptus plantation and natural regeneration on tropical soil. Forest Ecology and Management $174,1-11$.

Bisdom, E.B.A., Dekker, L.W., Schoute, J.F.T., 1993. Water repellency of sieve fractions from sandy soils and relationships with organic material and soil structure. Geoderma 56, $105-118$.

Black, C.A., 1965. Methods of soil analysis: part I physical and mineralogical properties. American society of agronomy, Madison, Wisconsin, USA

Bouillet, J.-P., Lacleau, J.-P., Arnaud, M., Thongo, M'Bou A, Saint-André, L., Jourdan, C. 2002. Changes with stand age in the spatial distribution of root of Eucalyptus clone in Congo: impact on water and nutrient uptake. Forest Ecology and Management 171, 43-57.

Brooksbank, K., Veneklaas, E.J., White, D.A., Carter, J.L., 2011. The fate of hydraulically redistributed water in a semi-arid zone Eucalyptus species. Tree Physiology 31, 1-10.

Butcher, T.B., 1977. Impact of moisture relationships on the management of Pinus Pinaster ait. plantations in Western Australia. Forest Ecology and Management 1 97-107.

Chan, K.Y., Bowman, A., Oates, A., 2001. Oxidizible organic carbon fractions and soil quality changes in an Oxic Paleustalf under different pasture leys. Journal of the Soil Science Society of America 166, 61-67.

Coelho, C.O.A., Laouina, A., Regaya, K., Ferreira, A.J.D., Carvalho, T.M.M., Chaker, M., Naafa, R., Naciri, R., Boulet, A.K., Keizer, J.J., 2005. The impact of soil water repellence on soil hydrological and erosional processes under Eucalyptus and evergreen Quercus forests in the Western Mediterranean. Australian Journal of Soil Research 43, 309-3198.

Crockford, H., Topalidis, S., Richardson, D.P., 1991. Water repellency in a dry sclerophyll eucalypt forest - measurements and processes. Hydrological Processes 5, 405-420.

D'Antonio, C., Meyerson, L.A., 2002. Exotic plant species as problems and solutions in ecological restoration: a synthesis. Restoration Ecology 10, 703-713.

De Villiers, S., 2007. The deteriorating nutrient status of the Berg River, South Africa. Water SA 33, 1-6.

DeBano, L.F., 1991. The effect of fire on soil properties. General Technical Report, INT-280. United States Department of Agriculture, Forest Service, pp. 151-156.

Dekker, L.W., Ritsema, C.J., 1994. How water moves in a water repellent sandy soil 1. Potential and actual water repellency. Water Resources Research 30, 2507-2517. 
Dekker, L.W., Oostindie, W.K., Ritsema, C.J., 2005. Exponential increase of publications related to soil water repellency. Australian Journal of Soil Research 43, 403-441.

Doerr, S.H., Thomas, A.D., 2000. The role of soil moisture in controlling water repellency: new evidence from forest soils in Portugal. Journal of Hydrology 231-232, 134-147.

Doerr, S.H., Thomas, A.D., 2003. Soil moisture: a controlling factor in water repellency. In: Ritsema, C.J., Dekker, L.W. (Eds.), Soil Water Repellency: Occurrence, Consequences and Amelioration. Elsevier Science, Amsterdam, pp. 137-149.

Doerr, S.H., Douglas, P., Evans, R.C., Morley, C.T., Mullinger, N.J., Bryant, R., Shakesby, R.A., 2005. Effects of heating and post heating equilibrium times on soil water repellency. Australian Journal of Soil Research 43, 261-267.

Dormaar, J.F., Carefoot, J.M., 1996. Implications of crop residue management and conservation tillage on soil organic matter. Canadian Journal of Plant Science 76, 627-634.

Dye, P.J., Poulter, A.G., 1995. A field demonstration of the effect on stream flow of clearing invasive pine and wattle trees from a riparian zone. Southern African Forestry Journal $173,27-30$.

Ehrenfeld, J.G., 2003. Effects of exotic plant invasions on soil nutrient cycling processes. Ecosystems 6, 503-523.

Eynard, A., Schumacher, T.E., Lindstrom, M.J., Malo, D.D., Kohl, R.A., 2004. Wettability of soil aggregates from cultivated and uncultivated Ustolls and Usterts. Australian Journal of Soil Research 42, 163-170.

Foord, J., Mangnall, M., Day, L., Ross-Gillespie, V., Ractliffe, G., 2008. River environmental management plan: Berg River and major tributaries within the Drakenstein Municipality of the Western Cape. Report for Drakenstein Municipality (Report No: 4769/402238).

Forsyth, G.G., Richardson, D.M., Brown, P.J., Van Wilgen, B.W., 2004. A rapid assessment of the invasive status of Eucalyptus species in two South African provinces. South African Journal of Science 100, 75-77.

Galatowitsch, S., Richardson, D.M., 2005. Riparian scrub recovery after clearing of invasive alien trees in headwater streams of the Western Cape, South Africa. Biological Conservation 122, 509-521.

Geldenhuys, C.J., 2008. Practical guidelines for the rehabilitation of forest-related streambank vegetation with removal of invader plant stands along the Berg River, Western Cape. Working for Water Report (FW - 02/08), South Africa.

Hallett, P.D., 2007. An introduction to soil water repellency. Proceedings of the 8th International Symposium on Adjuvants for Agrochemicals (ISAA2007), Columbus, OH, ISBN 978-0-473-12388-8.

Hallett, P.D., Nunan, N., Douglas, J.T., Young, I.M., 2004. Millimeter-scale spatial variability in soil water sorptivity: scale, surface elevation, and subcritical repellency effects. Soil Science Society of America Journal 68, 352-358.

Holmes, P.M., Richardson, D.M., Esler, K.J., Witkowski, E.T.F., Fourie, S., 2005. A decision-making framework for restoring riparian zones degraded by invasive alien plants in South Africa. South African Journal of Science 101, 553-564.

Holmes, P.M., Esler, K.J., Richardson, D.M., Witkowski, E.T.F., 2008. Guidelines for improved management of riparian zones invaded by alien plants in South Africa. South African Journal of Botany 74, 538-552.

Hölzel, N., Otte, A., 2003. Restoration of a species-rich flood meadow by topsoil removal and diaspore transfer with plant material. Applied Vegetation Science 6, 131-140.

Le Maitre, D.C., Versfeld, D.B., Chapman, R.A., 2000. The impact of invading alien plants on surface water resources in South Africa: a preliminary assessment. Water SA 26, 397-408.

Le Maitre, D.C., Gaertner, M., Marchante, E., Ens, E., Holmes, P.M., Pauchard, A., O'Farrell, P.J., Rogers, A.M., Blanchard, R., Blignaut, J., Richardson, D.M., 2011. Impacts of invasive Australian acacias: implications for management and restoration. Diversity and Distributions 17, 1015-1029.

Leighton-Boyce, G., Doerr, S.H., Shakesby, R.A., Walsh, R.P.D., Ferreira, A.D.J., Boulet, A.K., Coelho, C.O.A., 2005. Temporal dynamics of water repellency and soil moisture in Eucalypt plantations, Portugal. Australian Journal of Soil Research 43, 269-280.

Malkinson, D., Wittenberg, L., 2011. Post fire induced soil water repellency - modelling short and long-term processes. Geomorphology 125, 186-192.

Ma'shum, M., Farmer, V.C., 1985. Origin and assessment of water repellency of a sandy Australian soil. Australian Journal of Soil Research 23, 623-626.

Mataix-Solera, J., Arcenegui, V., Guerrero, C., Jordan, M.M., Dlapa, P., Tessler, N. Wittenberg, L., 2008. Can terra rosa become water repellent by burning? A laboratory approach. Geoderma 147, 178-184.
Moore, D., Kostka, S.J., Boerth, T.J., Franklin, M., Ritsema, C.J., Dekker, L.W., Oostindie, K. Stoof, C., Wesseling, J., 2010. The effect of soil surfactants on soil hydrological behavior, the plant growth environment, irrigation efficiency and water conservation. Journal of Hydrology and Hydromechanics 58, 142-148.

Mucina, L., Rutherford, M.C., 2006. The vegetation of South Africa, Lesotho and Swaziland. Strelitzia 19.South African National Biodiversity institute, Pretoria.

Peng, X., Zhang, B., Zhao, Q., Horn, R., Hallett, P.D., 2003. Influence of types of restorative vegetation on the wetting properties of aggregates in a severely degraded clayey Ultisol in subtropical China. Geoderma 115, 313-324.

Poore, M.E.D., Fries, C., 1985. The ecological effects of Eucalyptus. FAO For. Pap. 59. FAO, Rome, Italy.

Rhoades, J.D., 1982. Cation exchange capacity, In: Page, A.L., Miller, R.H., Keeney, D.R. (Eds.), Methods of Soil Analysis, 2nd ed. American Society of Agronomy, Madison. WI, pp. 149-157.

Richardson, D.M., Bond, W.J., Dean, W.R.J., Higgins, S.I., Midgley, G.F., Milton, S.J. Powrie, L., Rutherford, M.C., Samways, M.J., Schulze, R.E., 2000. Invasive alien organisms and global change: a south African perspective. In: Mooney, H.A., Hobbs, H.A. (Eds.), Invasive Species in a Changing World. Island press, Washington D.C., pp. 303-349.

Richardson, D.M., Holmes, P.M., Esler, K.J., Galatowitsch, S.M., Stromberg, J.C., Kirkman, S.P., Pyšek, P., Hobbs, R.J., 2007. Riparian zones - degradation, alien plant invasions and restoration prospects. Diversity and Distributions 13, 126-139.

Rodriguez-Alleres, M., Benito, E., 2011. Spatial and temporal variability of surface water repellency in sandy loam soils of NW Spain under Pinus pinaster and Eucalyptus globulus plantations. Hydrological Processes. http://dx.doi.org/10.1002/hyp. 8091.

Ruwanza, S., Gaertner, M., Esler, K.J., Richardson, D.M., in press. Both complete clearing and thinning of invasive trees lead to short-term recovery of native riparian vegetation in the Western Cape, South Africa. Applied Vegetation Science. http://dx.doi.org/10. 1111/j.1654-109X.2012.01222.x.

Sasikumar, K., Vijayalakshmi, C., Parthiban, K.T., 2002. Allelopathic effects of Eucalyptus on blackgram (Phaseolus mungo L.). Allelopathy Journal 9, 205-214.

Scott, D.F., 1993. The hydrological effects of fire in South African mountain catchments. Journal of Hydrology 150, 409-432.

Scott, D.F. 2000. Soil wettability in forested catchments in South Africa, as measured by different methods and as affected by vegetation cover and soil characteristics. Journal of Hydrology 231-232, 87-104.

Shakesby, R.A., Coelho, C.O.A., Ferreira, A.D., Terry, J.P., Walsh, R.P.D., 1993. Wildfire impacts on soil erosion and hydrology in wet Mediterranean forest, Portugal. International Journal of Wildland Fire 3, 95-110.

Slabbert, E., Kongor, R.Y., Esler, K.J., Jacobs, K., 2010. Microbial diversity and community structure in fynbos soil. Molecular Ecology 19, 1031-1041.

Srivastava, R.J., Kumar, A., Prasad, K., 2003. Studies on soil moisture variations under Eucalyptus plantation. XII World Forestry Congress (WFC), Quebec City, Canada.

StatSoft Inc, 2010. STATISTICA (Data Analysis Software System), Version 10. http://www. statsoft.com.

Tererai, F., 2012. The effects of invasive trees in riparian zones and implications for management and restoration: insights from Eucalyptus invasions in South Africa. $\mathrm{PhD}$ Thesis, Stellenbosch University.

Valat, B., Jouany, C., Riviere, L.M., 1991. Characterization of the wetting properties of air-dried peats and composts. Soil Science 152, 100-107.

Van Wilgen, B.W., Cowling, R.M., Le Maitre, D.C., 1998. Ecosystem services, efficiency, sustainability and equity: South Africa's Working for Water programme. Trends in Ecology \& Evolution 13, 378

Wallis, M.G., Horne, D.J., 1992. Soil water repellency. Advances in Soil Science 20, 91-146.

Yelenik, S.G., Stock, W.D., Richardson, D.M., 2004. Ecosystem impacts of invasive Acacia saligna in South African Fynbos. Restoration Ecology 12, 44-51.

Ziogas, A.K., Dekker, L.W., Oostindie, K., Ritsema, C.J., 2005. Soil water repellency in north-eastern Greece with adverse effects of drying on the persistence. Australian Journal of Soil Research 43, 281-289. 